\title{
Analysis of surface proteins of rat spermatozoa during epididymal transit and identification of antigens common to spermatozoa, rete testis fluid and cauda epididymal plasma
}

\author{
D. E. Brooks and K. Tiver \\ Department of Animal Sciences, Waite Agricultural Research Institute, University of Adelaide, \\ Glen Osmond, South Australia 5064, Australia
}

\begin{abstract}
Summary. Spermatozoa from the testis and cauda epididymidis of the rat were surface labelled with radioactive iodide, extracted with detergent, and the radioactive proteins separated by two-dimensional polyacrylamide gel electrophoresis. In some instances spermatozoa were also surface labelled with tritiated borohydride in the presence of galactose oxidase. Soluble proteins in blood serum, rete testis fluid and cauda epididymal plasma were also iodinated and separated by gel electrophoresis. In addition, aliquants of the radioactive sperm extracts, blood serum and reproductive tract fluids were each immunoprecipitated with polyspecific antisera directed against either testicular sperm membranes, caudal sperm membranes, blood serum, rete testis fluid or cauda epididymal plasma before gel electrophoresis. From the patterns of radioactive proteins detected on the resultant gels, a two-dimensional map was created for each of the sperm extracts and for the various fluids. Proteins which were nonhomologous between testicular and caudal spermatozoa were identified, as well as proteins which were common to spermatozoa and reproductive tract fluids. Epididymal transit was characterized by the loss of certain proteins from the sperm surface, including three borohydride-labelled proteins of $M_{r} 130000$, and by the addition of others, most notably a highly abundant protein of $M_{r} 42000$. Several of the proteins lost from spermatozoa accumulated in the epididymal plasma whilst some of those added to the sperm surface could be identified as direct secretory products of the epididymis. Rete testis fluid contained blood proteins in addition to others presumed to be testis-specific, whilst the composition of cauda epididymal plasma was markedly different from blood serum or rete testis fluid. Proteins that occurred in reproductivetract fluids and also on spermatozoa, but did not show a marked change in abundance on spermatozoa during epididymal transit, included transferrin, albumin and two closely related proteins of $M_{r} 22000$.
\end{abstract}

\section{Introduction}

It has become well documented that the sperm surface undergoes physical, chemical and functional modifications during the course of epididymal transit (see Brooks \& Tiver, 1983). Nevertheless, little is known about the changes in protein composition of the sperm plasma membrane which underlie these modifications. Insufficient material is available from small laboratory animals to permit bulk preparation of plasma membranes from spermatozoa of different maturational ages suitable for conventional protein staining on polyacrylamide gels. However, it is possible to 
radiolabel selectively the polypeptide chain of exposed sperm-surface proteins with radioactive iodide (e.g. Nicolson, Brodginski, Beattie \& Yanagimachi, 1979) or to label the exposed carbohydrate moiety of certain glycoproteins with tritiated borohydride (Olson \& Hamilton, 1978). Such labelled proteins can then be extracted from the spermatozoa and examined by analytical polyacrylamide gel electrophoresis. Studies of this type have been reported for epididymal spermatozoa of the mouse (Herr \& Eddy, 1980), hamster (Gabel, Eddy \& Shapiro, 1979), rat (Olson \& Hamilton, 1978; Jones, Pholpramool, Setchell \& Brown, 1981; Olson \& Danzo, 1981; Olson \& Orgebin-Crist, 1982; Vierula \& Rajaniemi, 1982; Wong, Tsang \& Lee, 1982; Brooks \& Tiver, 1983; Brown, von Glos \& Jones, 1983; Jones, von Glos \& Brown, 1983), rabbit (Nicolson et al., 1979; Oliphant \& Singhas, 1979), ram (Voglmayr, Fairbanks, Jackowitz \& Colella, 1980; Voglmayr, Fairbanks, Vespa \& Colella, 1982; Vierula \& Rajaniemi, 1982), bull (Vierula \& Rajaniemi, 1981, 1982), and boar (Vierula \& Rajaniemi, 1982). Similar analyses have been made with ejaculated spermatozoa of a number of species.

These studies have, almost without exception, relied upon one-dimensional gel electrophoretic systems which generally resolve only about 10 different radioiodinated proteins. However, it is now becoming clear that the surface protein composition of spermatozoa is too complex to be adequately resolved by such systems. For instance, separation of plasma membrane proteins of ejaculated boar spermatozoa by two-dimensional polyacrylamide gel electrophoresis can reveal up to 200 different polypeptides (Peterson, Russell, Hunt, Bundman \& Freund, 1983; Russell, Peterson, Russell \& Hunt, 1983). The objective of the present investigation has been to combine the technique of surface labelling of rat spermatozoa with two-dimensional gel electrophoresis to identify surface protein changes during sperm transport through the epididymis. In addition, immunoprecipitation of radioactive proteins with various polyspecific antisera before gel electrophoresis has been used as an aid to identify which antigens are common and which are not to immature and mature spermatozoa and to spermatozoa and reproductive tract fluids. This information will be of value in future studies of the origin and role of specific proteins in sperm maturation and gamete recognition.

\section{Materials and Methods}

Chemicals and animals. Details of the sources of chemicals have been given previously (Brooks, 1981; Brooks \& Tiver, 1983). Testicular and caudal spermatozoa were collected from adult male Sprague-Dawley rats and washed in phosphate-buffered saline as described previously (Brooks \& Tiver, 1983). Rete testis fluid and cauda epididymal plasma, collected by the same operative procedures as used for spermatozoa, were cleared of all particulate matter by centrifugation at $100000 \mathrm{~g}$ for $1 \mathrm{~h}$ at $2^{\circ} \mathrm{C}$. Blood was collected by heart puncture and allowed to clot. Serum was obtained by centrifugation of the clotted blood at $4000 \mathrm{~g}$ for $30 \mathrm{~min}$ at $2^{\circ} \mathrm{C}$. The protein content of these fluids was estimated by the procedure of Hartree (1972) using bovine serum albumin as the standard.

Radiolabelling of spermatozoa and reproductive-tract fluids. The procedures for surface labelling of spermatozoa, with tritiated borohydride in the presence of galactose oxidase or with ${ }^{125}$ I-iodide in the presence of Iodo-Gen, have been given previously (Brooks \& Tiver, 1983). The iodination procedure for soluble proteins has also been described (Brooks \& Tiver, 1983).

Production, processing and utilization of antisera. Polyspecific antisera were raised in rabbits against testicular and caudal sperm membranes as described previously (Brooks \& Tiver, 1983). Other antisera were raised by a similar protocol against blood serum, rete testis fluid and cauda epididymal plasma. In addition, antiserum against purified epididymal secretory proteins $\mathbf{B}$ and $\mathbf{C}$ (Brooks, 1981) and proteins D and E (Brooks, 1982) were also utilized. In all instances, the immunoglobulin fraction of the antiserum was prepared by ammonium sulphate fractionation as 
described previously (Brooks \& Tiver, 1983). The use of these antisera to immunoprecipitate radioactive proteins with the aid of Staphylococcus aureus before polyacrylamide gel electrophoresis has also been described (Brooks \& Tiver, 1983). Antisera against blood serum and reproductive tract fluids immunoprecipitated nearly all the radioiodinated proteins detectable in these fluids by two-dimensional polyacrylamide gel electrophoresis. On the other hand, antisera against sperm membranes recognized in radioiodinated sperm extracts predominantly proteins with a molecular weight greater than 30000 . The amount of radioactive protein immunoprecipitated by the various antisera was quantified by direct counting of samples in a gamma scintillation spectrometer.

Two-dimensional polyacrylamide gel electrophoresis. Two-dimensional gel electrophoresis was based on the procedure of O'Farrell (1975) as described by Brooks (1983). Isoelectric focussing in the first dimension was in tube gels containing pH 3.5-10 and pH 5-7 ampholines in the ratio 4:1 $(\mathrm{v} / \mathrm{v})$. Separation in the second dimension was in a slab gel with a gradient from 8 to $13 \%$ acrylamide. The $\mathrm{pH}$ profile of the first dimension tube gels was ascertained by sectioning a blank gel and extracting the segments into degassed water (O'Farrell, 1975). However, the presence of high concentrations of urea, as exist in two-dimensional gel electrophoresis, can alter both the determination of $\mathrm{pH}$ and the isoelectric point of a protein (O'Farrell, 1975). Calibration of migration in the second dimension was with standard marker proteins (Brooks, 1981) contained in side lanes. An internal standard of $25 \mu \mathrm{g}$ cauda epididymal plasma proteins was always added to each sample before two-dimensional gel electrophoresis to pinpoint the migration of particular proteins on the gel and to take account of small differences in running behaviour from one gel to the next. These internal standards, and the molecular weight markers, were located by staining the gels with Coomassie blue. Radioactive proteins were located by exposure to pre-flashed X-ray film at $-80^{\circ} \mathrm{C}$, either in the presence of an intensifying screen for ${ }^{125} \mathrm{I}$ or after impregnation with PPO for ${ }^{3} \mathrm{H}$ (Laskey, 1980).

\section{Results}

\section{Characteristics of sperm iodination and extraction}

Iodo-Gen was used in the present study to catalyse surface labelling of spermatozoa with ${ }^{125}$ Iiodide. Initial experiments were carried out to characterize the labelling conditions. First, it was ascertained that $2 \mu \mathrm{g}$ Iodo-Gen was the minimum required to obtain maximum incorporation of radioactive iodide into $2 \times 10^{6}$ spermatozoa contained in an iodination volume of $100 \mu$, whereas $10 \mu \mathrm{g}$ was required for $100 \mu \mathrm{g}$ soluble protein iodinated under the same conditions. Incorporation of label in the absence of Iodo-Gen was less than $2 \%$ of that in its presence. For spermatozoa, an average of $6.3 \pm 1.3 \%$ (mean \pm s.e.m. $n=9$ ) of the added radioactive iodide became incorporated; whereas for soluble proteins the incorporation was of the order of $90 \%$. Triton X-100 $(1 \%)$ or $1 \%$ Nonidet-P40 (NP-40) extracted $75 \%$ of the incorporated radioactivity from spermatozoa in $15 \mathrm{~min}$ at room temperature and produced similar two-dimensional gel patterns. Boiling of labelled spermatozoa in $1 \%$ sodium dodecyl sulphate (SDS) for 2 min extracted $85 \%$ of the incorporated radioactivity. However, two-dimensional gels of SDS extracts produced greater background fogging when exposed to X-ray film. Moreover, SDS extracts were not suitable for immunoprecipitation because SDS denatures the proteins. Therefore, all further studies were carried out using the detergent NP-40 as the extractant.

Based on the time required to obtain adequate autoradiographic exposures, it was estimated that only $10 \%$ of the radioactive iodide incorporated into spermatozoa was associated with protein, the remainder being associated with other material, presumed to be lipid. This result most probably reflects the fact that sperm phospholipids are particularly rich in highly unsaturated fatty acids (Poulos, Darin-Bennett \& White, 1973) whose double bonds would be expected to incorporate iodide readily. Because these lipids migrated to the bottom of the second-dimension slab gel, they did not interfere with the two-dimensional separation of proteins. 
Comparison of the patterns of labelled surface proteins extracted from testicular and caudal spermatozoa

Spermatozoa were iodinated on 7 separate occasions and 30 gels were run for whole extracts of spermatozoa and a similar number for immunoprecipitated samples of radioactive sperm extracts. Frequently each gel was placed with $\mathrm{X}$-ray film for various exposure times to detect those proteins with less intense labelling in addition to those that were heavily labelled. Information from such exposures was used to generate the two-dimensional maps of labelled proteins shown in Pl. 1, Fig. 1. Identification of proteins which were not common between testicular and caudal spermatozoa was based partly on non-coincident migration in the two-dimensional gel system and partly on the ability of various antisera differentially to immunoprecipitate specific proteins from radioactive extracts of the two sperm types. Because antisera against sperm membranes did not recognize some of the lower-molecular weight surface-labelled proteins (see 'Materials and Methods') the degree of homology between testicular and caudal spermatozoa and between spermatozoa and reproductive tract fluids (Table 1) may be an overestimate. There may well be additional differences in specific protein composition between testicular and caudal spermatozoa than those we have indicated. Our results are of a qualitative nature and we have been reluctant to assign differences between sperm types amongst the more minor constituents unless fully supported by immunoprecipitation results.

Our results (PI. 1, Fig. la, c) demonstrate that testicular spermatozoa possess several surface

Table 1. Comparative effectiveness of various antisera to immunoprecipitate radioactive proteins from radioiodinated blood serum, reproductive-tract fluids and spermatozoa

\begin{tabular}{lrrrrr}
\hline \multicolumn{5}{c}{ Antiserum against } & \multicolumn{5}{c}{ Source of radioactive protein } \\
\cline { 2 - 6 } \multicolumn{1}{c}{} & $\begin{array}{c}\text { Blood } \\
\text { serum }\end{array}$ & $\begin{array}{c}\text { Rete testis Cauda epididymal } \\
\text { fluid }\end{array}$ & plasma & $\begin{array}{c}\text { Testicular } \\
\text { spermatozoa }\end{array}$ & $\begin{array}{c}\text { Caudal } \\
\text { spermatozoa }\end{array}$ \\
\hline Blood serum & 100 & 102 & 5 & 7 & 6 \\
Rete testis fluid & 78 & 100 & 9 & 9 & ND \\
Cauda epididymal plasma & 12 & 26 & 100 & 10 & 20 \\
Testicular sperm membranes & ND & 5 & 4 & 100 & 52 \\
Caudal sperm membranes & 1 & 2 & 15 & 96 & 100 \\
Proteins B + C & ND & ND & 40 & 0 & 1 \\
Proteins D + E & ND & ND & 29 & 0 & 5 \\
\hline
\end{tabular}

ND, not determined.

Values represent the percentage of radioactivity immunoprecipitated from each fluid or sperm extract relative to the radioactivity immunoprecipitated by the homologous antiserum. Comparisons within the table should be made vertically and not horizontally.

\section{PLATE 1}

Fig. 1. Two-dimensional gel electrophoresis of radioactive proteins extracted from testicular $(a, c)$ and caudal $(b, d)$ spermatozoa after surface labelling with radioactive iodide. A representative two-dimensional gel separation of iodinated proteins from testicular and caudal spermatozoa is shown in (a) and (b), respectively. Two-dimensional maps drawn from such gels are shown in (c) and (d). In the maps each circle represents an identifiable radioactive protein ascertained from several gels with each gel being placed with film for a variety of exposure times. The thickness of the line creating the circle provides a semi-quantitative estimate of the relative intensity of the radioactive spot, with thicker lines being used for more intense spots. The diameters of the circles are the approximate areas occupied by the spots at one particular exposure. The broken line represents the top of the resolving gel. The positions of albumin (A) and previously characterized epididymal secretory proteins (B, C, D and E) are shown; numbers $\left(M_{r} \times 10^{-3}\right)$ indicate various proteins to which specific reference is made in the text. Filled-in circles in (c) are proteins on testicular spermatozoa which were unequivocally absent from caudal spermatozoa. Filled-in circles in (d) are proteins on caudal spermatozoa which were absent from or much less intense on testicular spermatozoa. 
PLATE 1

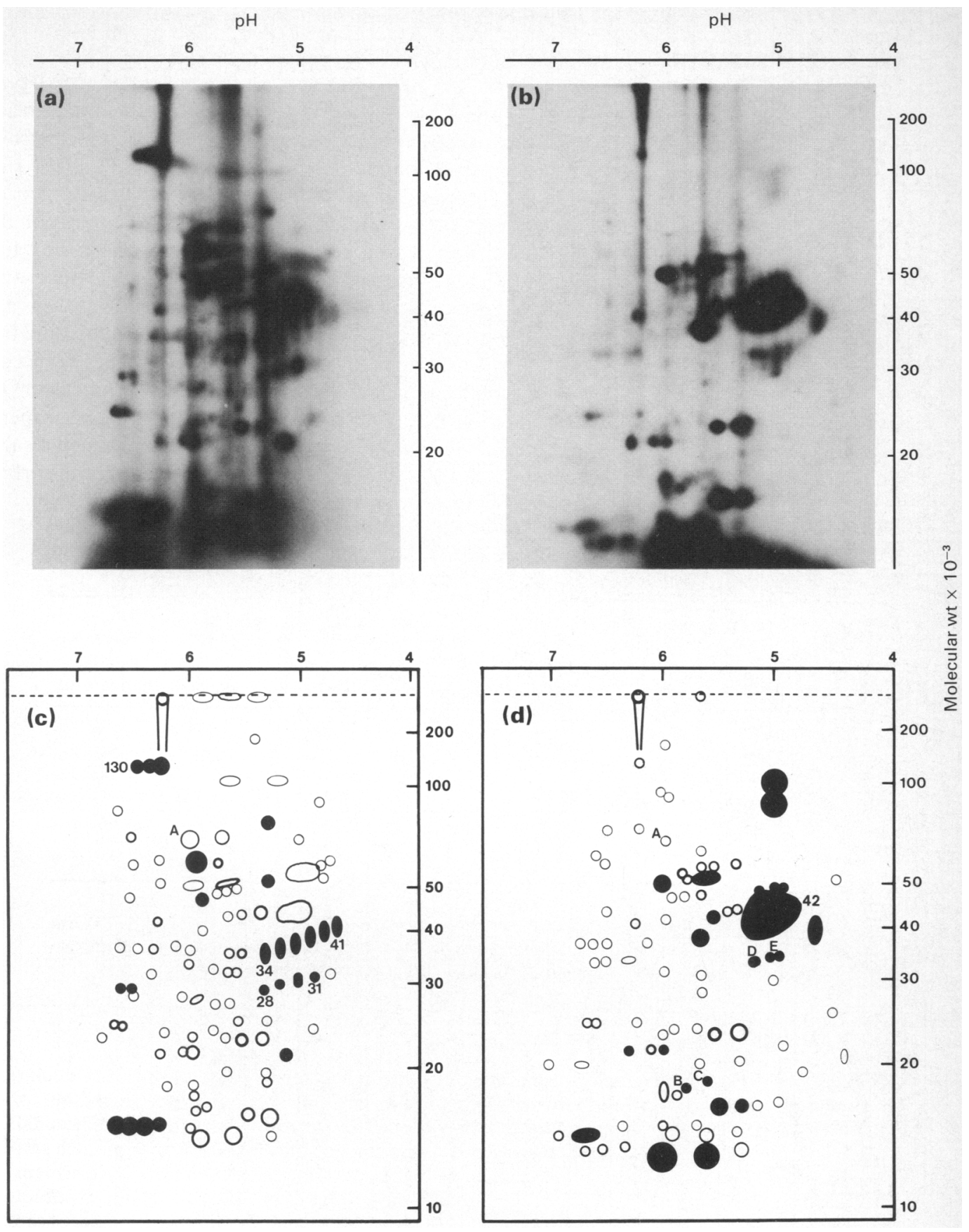

(Facing p. 252) 


\section{PLATE 2}

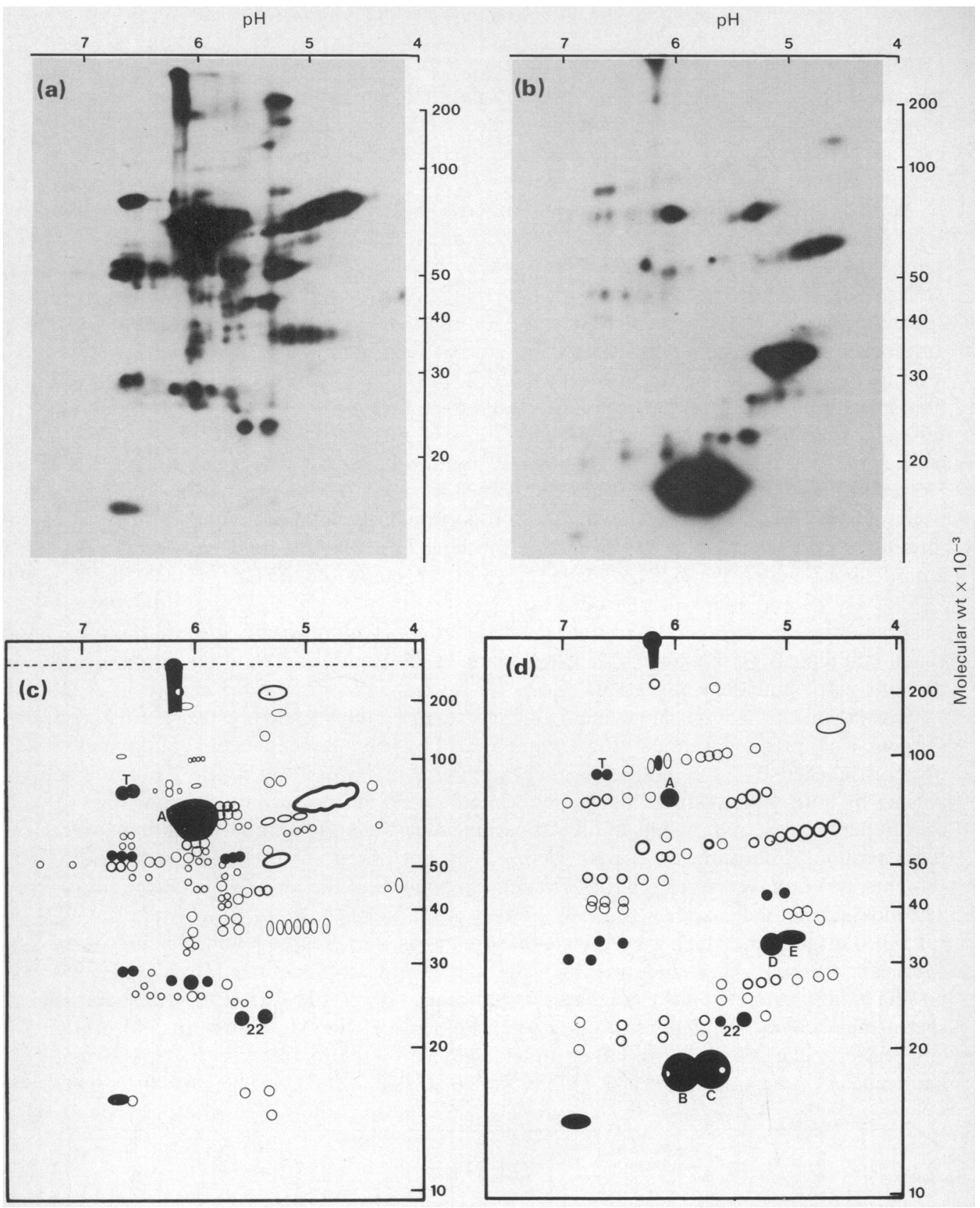


proteins which are apparently lost or masked during epididymal transit since they were not detected on caudal spermatozoa. Conversely, caudal spermatozoa contain proteins which were not evident on testicular spermatozoa (Pl. 1, Fig. 1b, d) and which were presumably acquired during the course of epididymal transit. The extent of the change during epididymal transit appears quite major since antiserum against testicular sperm membranes immunoprecipitated from labelled caudal spermatozoa extracts only half of the radioactivity immunoprecipitated by antiserum against caudal sperm membranes (Table 1).

Some particular features can be noted amongst those proteins that were present on testicular spermatozoa but not detected on caudal spermatozoa (Pl. 1, Fig. 1a, c). The three closely migrating spots at $\mathrm{M}_{\mathrm{r}} 130000$ (pI 6.2-6.5) coincide with proteins which label with tritiated borohydride in the presence of galactose oxidase. Although it was difficult to detect any of these proteins on caudal spermatozoa, some must be present since antiserum to caudal sperm membranes contained antibodies against them. The two series of proteins stretching from $\mathrm{M}_{\mathrm{r}} 34000$ (pI 5.3) to 41000 (pI 4.7) and from 28000 (pI 5.3) to 31000 (pI 4.9) (Pl. 1, Fig. 1c) apparently accumulated in epididymal fluid as a result of their release from testicular spermatozoa: they were immunoprecipitated from testicular spermatozoa, but not caudal spermatozoa or rete testis fluid, by antiserum against cauda epididymal plasma and were not recognized by antiserum against caudal sperm membranes. However, these proteins were not all readily seen in cauda epididymal plasma (Pl. 2, Fig. 2b, d) because they probably represented a minor proportion of the total protein with the result that the intensity of the label in more abundant proteins obscured the relevant areas when longer autoradiographic exposures were made. The other proteins $\left(M_{r} 66000,58000,52000,46000\right.$, 28500,21000 and 14000 ) lost from testicular spermatozoa (P1. 1, Fig. 1c) did not appear to accumulate in epididymal plasma since (a) they did not elicit antibodies after immunization with cauda epididymal plasma and (b) labelled cauda epididymal plasma did not contain radioactive proteins with coincident migration.

Several specific features are evident amongst those proteins gained by the spermatozoa during the course of epididymal transit (Pl. 1, Fig. 1b, d). The androgen-dependent epididymal secretory proteins labelled B, C, D and E were all immunoprecipitated from labelled cauda epididymal plasma by antiserum against caudal sperm membranes, but not by antiserum against testicular sperm membranes, and specific antisera raised against the purified proteins immunoprecipitated these proteins from labelled caudal spermatozoa but not from testicular spermatozoa. These proteins, however, represent relatively minor components of the total labelled proteins (Table 1). The most substantial change was due to the very prominent labelled protein centered at $M_{r} 42000$ (pI 5.0). This protein, which was very much more intense in caudal than in testicular spermatozoa, overlies two closely migrating proteins which could be immunoprecipitated from cauda epididymal plasma by antiserum against caudal sperm membranes (Pl. 2, Fig. 2d). Antiserum against caudal sperm membranes immunoprecipitated small amounts of the $M_{r} 42000$ (pI 5.0) protein from labelled testicular spermatozoa. Other proteins gained by spermatozoa during epididymal transit have molecular weights of $100000,85000,51000,48000,42000,40000,36000,21000,15000$,

\section{PLATE 2}

Fig. 2. Two-dimensional gel electrophoresis of radioiodinated proteins of rete testis fluid (a, c) and cauda epididymal plasma $(b, d)$. A representative two-dimensional gel separation of iodinated proteins in rete testis fluid and cauda epididymal plasma is shown in (a) and (b), respectively. Two-dimensional maps drawn from such gels are shown in (c) and (d). The conventions adopted in drawing the maps are explained in the legend to Pl. 1, Fig. 1. The positions of transferrin (T), albumin (A), and previously characterized epididymal secretory proteins $(B, C, D$ and $E)$ are shown; numbers $\left(M_{r} \times 10^{-3}\right)$ indicate various proteins to which specific reference is made in the text. Filled-in circles in (c) are proteins of rete testis fluid which were also present on testicular spermatozoa. Filled-in circles in (d) are proteins of cauda epididymal plasma which were also present on caudal spermatozoa. 
13000 and 12000 (P1. 1, Fig. 1d). In contrast to the situation with testicular spermatozoa, it was not possible unequivocally to correlate radioiodinated caudal sperm proteins with those proteins that can be labelled with tritiated borohydride (four proteins of $M_{r} 28000$; see Brooks \& Tiver, 1983).

Several proteins present in rete testis fluid and in cauda epididymal plasma were also associated with the surface of testicular and cauda epididymal spermatozoa (Pl. 2, Fig. 2). This could be deduced by immunoprecipitation of these fluids with antiserum against testicular sperm membranes and against caudal sperm membranes. This group of common proteins includes transferrin, albumin and two proteins of $\mathrm{M}_{\mathrm{r}} 22000$ (pI 5.5 and pI 5.3). The more basic protein of this pair is one of the major proteins of spermatozoa, rete testis fluid and cauda epididymal plasma, judging from the intensity of the Coomassie-staining pattern of two-dimensional gels; its more acidic partner stained much less intensely with Coomassie blue but labelled more intensely with radioactive iodide (results not shown).

Other proteins of rete testis fluid which are apparently also associated with testicular spermatozoa, since they were immunoprecipitated by antiserum against testicular sperm membranes, are indicated in Pl. 2, Fig. 2c. Similarly, proteins of cauda epididymal plasma also associated with caudal spermatozoa, as revealed by antiserum against caudal sperm membranes, are indicated in $\mathrm{Pl}$. 2, Fig. 2d.

\section{Comparison of the proteins of blood serum, rete testis fluid and cauda epididymal plasma}

Two-dimensional gel patterns of radioiodinated proteins from rete testis fluid and cauda epididymal plasma are presented in Pl. 2, Fig. 2 and Text-fig. 1. Rete testis fluid contained many blood proteins, but this may have resulted from contamination with some testicular lymph during the course of collection. The average protein content of rete testis fluid collected in this study was $2.3 \mathrm{mg} / \mathrm{ml}$; values reported by other workers have ranged from 1.2 to $5.7 \mathrm{mg} / \mathrm{ml}$ (French \& Ritzén,

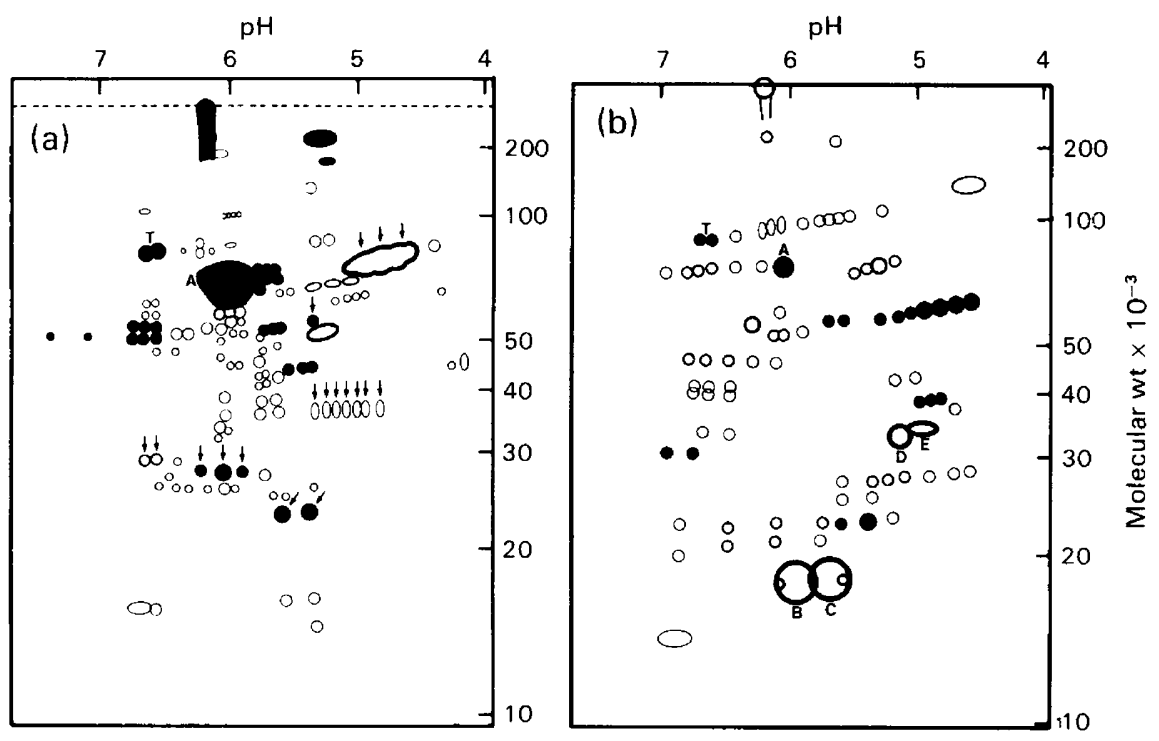

Text-fig. 1. Two-dimensional maps of radioiodinated proteins of (a) rete testis fluid and (b) cauda epididymal plasma indicating proteins common to the two fluids. The maps were drawn from gels as described in the legend to Pl. 2, Fig. 2. Filled-in circles in (a) are proteins of rete testis fluid that were recognized by antiserum against cauda epididymal plasma: proteins which are arrowed are those that were absent from or far more pronounced than in blood serum. Filled-in circles in (b) are proteins of cauda epididymal plasma which were recognized by antiserum against rete testis fluid. 
1973; Koskimies \& Kormano, 1973; Main \& Waites, 1977; Setchell et al., 1978; Turner, Plesums \& Cabot, 1979). However, a small contamination by volume with testicular lymph, which contains about $50 \mathrm{mg} / \mathrm{ml}$ protein (Setchell, 1970), would result in substantial contamination with lymph proteins. Nevertheless, comparison of the labelled protein patterns for rete testis fluid with blood serum did reveal the presence of several testis-specific proteins in rete testis fluid; these are indicated in Text-fig. 1(a). A comparision of cauda epididymal plasma with rete testis fluid reveals that not only is there more than a 10 -fold increase in protein concentration of the testicular effluent during passage through the epididymis $(2.3 \mathrm{mg} / \mathrm{ml}$ in rete testis fluid (present study) compared with $33 \mathrm{mg} / \mathrm{ml}$ in cauda epididymal plasma (Back, Shenton \& Glover, 1974; Jones, 1978; Turner et al., 1979; Turner \& Giles, 1982)), but there is also a marked alteration in protein composition. This interpretation is supported by the fact that relatively few of the proteins in rete testis fluid were recognized by antiserum against cauda epididymal plasma (Table 1; Text-fig. 1a) and, conversely, few of the proteins of cauda epididymal plasma were recognized by antiserum against rete testis fluid (Table 1; Text-fig. 1b). The most intensely labelled proteins in cauda epididymal plasma were proteins $\mathrm{B}$ and $\mathrm{C}$ and proteins $\mathrm{D}$ and $\mathrm{E}$, which accounted for $40 \%$ and $29 \%$ respectively of the total radioactivity of labelled cauda epididymal plasma (Table 1).

\section{Discussion}

The two-dimensional analysis of radioiodinated testicular and caudal sperm surface proteins reported in the present study confirms similar work in other species with spermatogenic cells (Millette \& Moulding, 1981a, b) and with ejaculated spermatozoa (Peterson et al., 1983; Russell et al., 1983) in demonstrating that the surface composition of the male gamete consists of a highly complex mixture of polypeptides. The composition may be even more complex than that presented here since we have excluded from our study those proteins possessing a basic isoelectric point (see O'Farrell, Goodman \& O'Farrell, 1977). Moreover, the greater exposure times required to identify more minor components on the X-ray film meant that such proteins were obscured when in the immediate vicinity of more intensely labelled proteins.

Our analysis has revealed that some proteins present on testicular spermatozoa are lost or masked during the course of epididymal transit. One of the more obvious examples is a group of three proteins of $\mathrm{M}_{\mathrm{r}} 130000$ susceptible to labelling with tritiated borohydride in the presence of galactose oxidase. Several of the proteins lost from testicular spermatozoa accumulate as soluble moieties in epididymal plasma. Other proteins are gained by the spermatozoa during the course of epididymal transit. As a result of these changes the surface polypeptide composition of caudal spermatozoa is markedly different from that of testicular spermatozoa. Quantitatively, the most pronounced change is the acquisition of a protein of $M_{r} 42000$. Small amounts of a protein with identical gel migration could be detected by various antisera in testicular sperm extracts and in cauda epididymal plasma. Moreover, the migration position of this protein was coincident with an androgen-dependent secretory protein identified in a previous study (Brooks, 1983) as being synthesized in all regions of the epididymis. In that study the protein was assigned a molecular weight of 41000 . It therefore seems that this protein is already present on the surface of testicular spermatozoa but that continued secretion by the epididymis and binding to the spermatozoon leads to a massive increase in its abundance on the spermatozoa, without any increase in its concentration in epididymal luminal fluid. By contrast, other proteins represent entirely new additions to the sperm surface. This is the case for the androgen-dependent epididymal-specific secretory proteins $\mathrm{B}, \mathrm{C}, \mathrm{D}$, and $\mathrm{E}$, whose addition to spermatozoa we have demonstrated previously (Brooks \& Tiver, 1983). However, unlike the $M_{r} 42000$ protein, only small amounts of these proteins become associated with the spermatozoa whilst large amounts accumulate in the epididymal luminal fluid (Brooks \& Higgins, 1980; present study).

There are other proteins which are present both on spermatozoa and in reproductive-tract fluids 
but which change little in their relative abundance on the sperm surface during the course of epididymal transit. This is the case for transferrin, albumin and a pair of proteins of $M_{r} 22000$ (pI 5.5 and 5.3). Transferrin arises in rete testis fluid as a result of synthesis and secretion by Sertoli cells (Skinner \& Griswold, 1980; Wright, Musto, Mather \& Bardin, 1981). Albumin is also a normal component of seminiferous tubule fluid and rete testis fluid (Koskimies \& Kormano, 1973; Turner et al., 1979; Voglmayr et al., 1980) but it is not a synthetic product of the testis (unpublished observations) and hence is presumably derived from the blood stream. The protein of $M_{r} 22000$ (pI 5.5) corresponds to the protein $A^{\prime}$ which we have described previously (Brooks \& Higgins, 1980). Its more acidic partner appears to be formed from the authentic protein during the course of radioiodination (unpublished observations). We have established that the testis and all regions of the epididymis (initial segment, caput, corpus and cauda) synthesize from $\left[{ }^{35} \mathrm{~S}\right] \mathrm{methionine}$ in vitro a cytosolic protein which has coincident migration with the 22000 protein on two-dimensional gels. However, secretion of the protein into the medium could only be detected for the testis and the cauda epididymidis (unpublished observations).

Although our present results have demonstrated major differences in the polypeptide composition of the sperm plasma membrane during the course of epididymal transit, future studies will need to be directed towards establishing where these proteins are located on the sperm surface and ultimately towards identifying specific roles for particular proteins. Our own work with affinity-purified polyclonal antibodies (Brooks \& Tiver, 1983) and that of others with monoclonal antibodies (Feuchter, Vernon \& Eddy, 1981; Myles, Primakoff \& Bellvé, 1981; Schmell, Yuan, Gulyas \& August, 1981 ; Gaunt, 1982; Schmell, Gulyas, Yuan \& August, 1982; Crichton \& Cohen, 1983; Gaunt, Brown \& Jones, 1983; Primakoff \& Myles, 1983) reveal that the sperm plasma membrane is a highly differentiated structure with particular antigens being restricted to specific domains of the sperm surface. Assortment of antigens into specific surface domains is clearly intimately involved with the specialized tasks which each component of the spermatozoon is required to perform.

\section{References}

Back, D.J., Shenton, J.C. \& Glover, T.D. (1974) The composition of epididymal plasma from the cauda epididymidis of the rat. J. Reprod. Fert. 40, 211-214.

Brooks, D.E. (1981) Secretion of proteins and glycoproteins by the rat epididymis: regional differences, androgen-dependence, and effects of protease inhibitors, procaine and tunicamycin. Biol. Reprod. 25, 1099-1117.

Brooks, D.E. (1982) Purification of rat epididymal proteins ' $D$ ' and ' $E$ ', demonstration of shared immunological determinants, and identification of regional synthesis and secretion. Int. J. Androl. 5, 513-524.

Brooks, D.E. (1983) Effect of androgens on protein synthesis and secretion in various regions of the rat epididymis, as analysed by two-dimensional gel electrophoresis. Molec. cell. Endocr. 29, 255-270.

Brooks, D.E. \& Higgins, S.J. (1980) Characterization and androgen-dependence of proteins associated with luminal fluid and spermatozoa in the rat epididymis. J. Reprod. Fert. 59, 363-375.

Brooks, D.E. \& Tiver, K. (1983) Localization of epididymal secretory proteins on rat spermatozoa. J. Reprod. Fert. 69, 651-657.

Brown, C.R., von Glos, K.I. \& Jones, R. (1983) Changes in plasma membrane glycoproteins of rat spermatozoa during maturation in the epididymis. J. Cell Biol. 96, 256-264.
Crichton, D.N. \& Cohen, B.B. (1983) Analysis of the murine sperm surface with monoclonal antibodies. $J$. Reprod. Fert. 68, 497-505.

Feuchter, F.A., Vernon, R.B. \& Eddy, E.M. (1981) Analysis of the sperm surface with monoclonal antibodies: topographically restricted antigens appearing in the epididymis. Biol. Reprod. 24, 10991110.

French, F.S. \& Ritzén, E.M. (1973) Androgen-binding protein in efferent duct fluid of rat testis. $J$. Reprod. Fert. 32, 479-483.

Gabel, C.A., Eddy, E.M. \& Shapiro, B.M. (1979) Regional differentiation of the sperm surface as studied with ${ }^{125} \mathrm{I}$-diiodofluorescein isothiocyanate, an impermeant reagent that allows isolation of the labeled components. $J$. Cell Biol. 82, 742-754.

Gaunt, S.J. (1982) A 28K-dalton cell surface autoantigen of spermatogenesis: characterization using a monoclonal antibody. Devl Biol. 89, 92-100.

Gaunt, S.J., Brown, C.R. \& Jones, R. (1983) Identification of mobile and fixed antigens on the plasma membrane of rat spermatozoa using monoclonal antibodies. Expl Cell Res. 144, 275-284.

Hartree, E.F. (1972) Determination of protein: a modification of the Lowry method that gives a linear photometric response. Analyt. Biochem. 48, $422-427$.

Herr, J.C. \& Eddy, E.M. (1980) Detection of mouse 
sperm antigens by a surface labeling and immunoprecipitation approach. Biol. Reprod. 22, 1263-1274.

Jones, R. (1978) Comparative biochemistry of mammalian epididymal plasma. Comp. Biochem. Physiol. 61B, 365-370.

Jones, R., Pholpramool, C., Setchell, B.P. \& Brown, C.R. (1981) Labelling of membrane glycoproteins on rat spermatozoa collected from different regions of the epididymis. Biochem. J. 200, 457-460.

Jones, R., von Glos, K.I. \& Brown, C.R. (1983) Changes in the protein composition of rat spermatozoa during maturation in the epididymis. J. Reprod. Fert. 67, 299-306.

Koskimies, A.I. \& Kormano, M. (1973) The proteins in fluids from the seminiferous tubules and rete testis of the rat. J. Reprod. Fert. 34, 433-444.

Laskey, R.A. (1980) The use of intensifying screens or organic scintillators for visualizing radioactive molecules resolved by gel electrophoresis. Meth. Enzymol. 65, 363-371.

Main, S.J. \& Waites, G.M.H. (1977) The blood-testis barrier and temperature damage to the testis of the rat. J. Reprod. Fert. 51, 439-450.

Millette, C.F. \& Moulding, C.T. (1981a) Cell surface marker proteins during mouse spermatogenesis: twodimensional electrophoretic analysis. J. Cell Sci. $\mathbf{4 8}$, 367-382.

Millette, C.F. \& Moulding, C.T. (1981b) Radio-iodination of plasma membrane polypeptides from isolated mouse spermatogenic cells. Gamete Res. 4, 317-331.

Myles, D.G., Primakoff, P. \& Bellvé, A.R. (1981) Surface domains of the guinea pig sperm defined with monoclonal antibodies. Cell 23, 433-439.

Nicolson, G.L., Brodginski, A.B., Beattie, G. \& Yanagimachi, R. (1979) Cell surface changes in the proteins of rabbit spermatozoa during epididymal passage. Gamete Res. 2, 153-162.

O'Farrell, P.H. (1975) High resolution two-dimensional electrophoresis of proteins. J. biol. Chem. 250, 40074021 .

O'Farrell, P.Z., Goodman, H.M. \& O'Farrell, P.H. (1977) High resolution two-dimensional electrophoresis of basic as well as acidic proteins. Cell 12, $1133-1142$.

Oliphant, G. \& Singhas, C.A. (1979) Iodination of rabbit sperm plasma membrane: relationship of specific surface proteins to epididymal function and sperm capacitation. Biol Reprod. 21, 937-944.

Oison, G.E. \& Danzo, B.J. (1981) Surface changes in rat spermatozoa during epididymal transit. Biol. Reprod. 24, 431-443.

Olson, G.E. \& Hamilton, D.W. (1978) Characterization of the surface glycoproteins of rat spermatozoa. Biol. Reprod. 19, 26-35.

Olson, G.E. \& Orgebin-Crist, M.-C. (1982) Sperm surface changes during epididymal maturation. Ann. N.Y. Acad. Sci. 383, 372-391

Peterson, R.N., Russell, L.D., Hunt, W., Bundman, D. \& Freund, M. (1983) Characterization of boar sperm plasma membranes by two-dimensional PAGE and isolation of specific groups of polypeptides by anion exchange chromatography and lectin affinity chromatography. J. Androl. 4, 71-81.

Poulos, A., Darin-Bennett, A. \& White, I.G. (1973) The phospholipid-bound fatty acids and aldehydes of mammalian spermatozoa. Comp. Biochem. Physiol. 46B, $541-549$.

Primakoff, P. \& Myles, D.G. (1983) A map of the guinea pig sperm surface constructed with monoclonal antibodies. Devl Biol. 98, 417-428.

Russell, L.D., Peterson, R.N., Russell, T.A. \& Hunt, W. (1983) Electophoretic map of boar sperm plasma membrane polypeptides and localization and fractionation of specific polypeptide subclasses. Biol. Reprod. 28, 393-413.

Schmell, E.D., Yuan, L.C., Gulyas, B.J. \& August, J.T. (1981) Identification of mammalian sperm surface antigens. I. Production of monoclonal anti-mouse sperm antibodies. Fertil. Steril. 37, 249-257.

Schmell, E.D., Gulyas, B.J., Yuan, L.C. \& August, J.T. (1982) Identification of mammalian sperm surface antigens. II. Characterization of an acrosome cap protein and a tail protein using monoclonal antimouse sperm antibodies. J. Reprod. Immunol. 4, 91106.

Setchell, B.P. (1970) Testicular blood supply, lymphatic drainage, and secretion of fluid. In The Testis, pp. 101-239. Eds A. D. Johnson, W. R. Gomes \& N. L. VanDemark. Academic Press, New York.

Setchell, B.P., Davies, R.V., Gladwell, R.T., Hinton, B.T., Main, S.J., Pilsworth, L. \& Waites, G.M.H. (1978) The movement of fluid in the seminiferous tubules and rete testis. Annls Biol. anim. Biochim. Biophys. 18, 623-632.

Skinner, M.K. \& Griswold, M.D. (1980) Sertoli cells synthesize and secrete transferrin-like protein. J. biol. Chem. 255, 9523-9525.

Turner, T.T. \& Giles, R.D. (1982) Sperm motilityinhibiting factor in rat epididymis. Am. J. Physiol. 242, R199-R203.

Turner, T.T., Plesums, J.L. \& Cabot, C.L. (1979) Luminal fluid proteins of the male rat reproductive tract. Biol. Reprod. 21, 883-890.

Vierula, M. \& Rajaniemi, H. (1981) Changes in surface protein structure of bull spermatozoa during epididymal maturation. Int. J. Androl. 4, 314-320.

Vierula, M. \& Rajaniemi, H. (1982) Epididymal maturation of the surface protein structure of mammalian spermatozoa. Med. Biol. 60, 323-327.

Voglmayr, J.K., Fairbanks, G., Jackowtiz, M.A. \& Colella, J.R. (1980) Post-testicular developmental changes in the ram sperm cell surface and their relationship to luminal fluid proteins of the reproductive tract. Biol. Reprod. 22, 655-667.

Voglmayr, J.K., Fairbanks, G., Vespa, D.B. \& Colella, J.R. (1982) Studies on mechanisms of surface modifications in ram spermatozoa during the final stages of differentiation. Biol. Reprod. 26, 483-500.

Wong, P.Y.D., Tsang, A.Y.F. \& Lee, W.M. (1982) Secretion of macromolecules by the rat epididymis. Int. J. Androl., Suppl. 5, 34-47.

Wright, W.W., Musto, N.A., Mather, J.P. \& Bardin, C.W. (1981) Sertoli cells secrete both testis-specific and serum proteins. Proc. natn. Acad. Sci. U.S.A. 78, 7565-7569. 